\title{
ЕКОНОМІКА
}

УДК 633.854.78: 631.51.021: 338.31

(C) 2016

Компанісць В. О., кандидат економічних наук,

Кулик А. О., головний фахівець лабораторії економічних та маркетингових досліджень

Інститут зернових культур НААН України

Кохан А. В., кандидат сільськогосподарських наук

Полтавська державна сільськогосподарська дослідна станція ім. М. І. Вавилова IC і АПВ

\section{ЕКОНОМІЧНА ЕФЕКТИВНІСТЬ ЗАСТОСУВАННЯ СПОСОБІВ ОСНОВНОГО ОБРОБІТКУ ІРУНТУ В ТЕХНОЛОГІЇ ВИРОЩУВАННЯ СОНЯШНИКУ}

\section{Рецензент - доктор сільськогосподарських наук І. Д. Ткаліч}

Здійснено економічну оцінку результатів експериментальних досліджень з визначення ефективності застосування різних способів основного обробітку трунту в технологї вирошування соняшнику в трунтово-кліматичних умовах Північного Степу України. Дослідження проводилися на базі Державного підприємства Дослідного господарства «Дніпро» ДУ Інституту зернових культур НААН. За результатами комплексної оцінки сформульовано рекомендації щзодо підвищення врожайності та рентабельності виробництва насіння соняшнику на основі застосування найбільш ефективних способів основного обробітку трунту.

Ключові слова: сонячник, способи основного обробітку трунту, урожайність, собівартість, чистий дохід, рентабельність.

Постановка проблеми. Займаючи одне 3 провідних місць серед держав-виробників насіння соняшнику, Україна традиційно забезпечує близько $10 \%$ обсягів його світового виробництва. 3окрема, за період з 2000 по 2014 рр. валові збори насіння соняшнику в Україні збільшилися з 3457 до 10134 тис. тонн.

Відомо, що для вітчизняних сільськогосподарських товаровиробників вирощування технічних культур $\epsilon$ важливим джерелом надходження грошових коштів та підтримання рентабельного ведення агробізнесу. Проте саме висока ефективність виробництва насіння соняшнику та продуктів його переробки призвели до надмірного розширення площі посівів даної олійної культури не лише в регіонах традиційного вирощування, але й практично в усіх природно-економічних зонах України. Так, протягом 2000-2014 рр. збиральні площі соняшнику в Україні збільшилися з 2842 до 5212 тис. га (максимального рівня за останні 5 років). Переважання екстенсивних тенденцій в розвитку цієї галузі призвело до появи цілої низки негативних наслідків: порушення системи сівозмін, зниження родючості грунту, погіршен- ня фітосанітарної ситуації тощо. Через надмірне насичення сівозмін соняшником погіршилися умови для вирощування решти сільськогосподарських культур.

Дотримання науково обгрунтованих принципів сівозмінного впорядкування земельної площі, зокрема передбачених Постановою КМУ від 11 лютого 2010 р. № 164 «Про затвердження нормативів оптимального співвідношення культур у сівозмінах у різних природно-сільськогосподарських регіонах» [1], вимагає концентрації зусиль на інтенсивному шляху розвитку галузі рослинництва. У цьому контексті особливої актуальності набувають дослідження проблеми нарощування обсягів виробництва високоякісного насіння соняшнику за рахунок підвищення його врожайності у випадку зменшення площ посіву. Виявлення резервів збільшення продуктивності соняшнику та покращання якості продукції знаходиться передусім у площині вдосконалення технології вирощування даної культури та застосування прогресивних агротехнічних заходів. Серед них у сучасних умовах важливого значення набуває пошук найбільш ефективних 3 технологічної та економічної точок зору систем обробітку грунту.

Аналіз останніх досліджень і публікацій, у яких започатковано розв'язання проблеми. Дослідженням теоретичних і практичних аспектів підвищення ефективності виробництва соняшнику займаються багато науковців, зокрема відомі вітчизняні вчені-економісти: В. Г. Андрійчук, Ю. В. Бабенко, В. І. Бойко, О.В.Воронянська, П. І. Гайдуцький, М. В. Гладій, О. Д. Гудзинський, Ю. В. Домашенко, Л. А. Євчук, О. В. Крисальний, С. Ю. Кучеренко, І. І. Лукінов, П. М. Макаренко, П. Т. Саблук, В. С. Уланчук, В. П. Федоряка, М. Й. Хорунжий, Л. Г. Чернюк, О. М. Шпичак та інші.

Обробіток грунту - це ключовий елемент сис- 


\section{ЕКОНОМІКА}

теми землеробства. Обгрунтовано вибраний спосіб основного обробітку в комплексі з іншими агроприйомами технології вирощування, що значною мірою визначає ефективність вирощування культури. За допомогою обробітку регулюють фізичні властивості та основні грунтові режими: водний, температурний, поживний тощо; знищують бур'яни, загортають добрива й насіння в грунт. На виконання обробітку витрачається значна частка енергіï, спрямованої на виробництво рослинницької продукції.

В Україні впродовж тривалого часу домінував інтенсивний обробіток, заснований на оранці, який не завжди був обумовлений потребою оптимізувати агрофізичний стан грунту та основні його режими. Такий обробіток за нестачею органічних і мінеральних добрив стимулював процеси мінералізації органічних речовин, завдяки чому підтримувались родючість грунту і продуктивність сільськогосподарських культур на певному рівні. Наслідки інтенсивних технологій на основі полицевого обробітку загальновідомі: це суттєве зниження вмісту гумусу, зростання площ деградованих земель, підсилення ерозійних процесів тощо. Інтенсивні технології вирощування культур передбачають багаторазові проходи машино-тракторних агрегатів (МТА) по полю. Наслідком цього $є$ переущільнення орного i, навіть, підорного шарів грунту, що призводить до руйнування структури, погіршення агрофізичних показників грунту, підсилення ерозійних процесів. Процес зниження ефективної родючості грунту під впливом рушіїв МТА має кумулятивний характер. За даними літературних джерел переущільнення грунту обумовлює втрати врожайності сільськогосподарських культур до 18-40 \% $[15,17]$.

Результати наукових досліджень свідчать, що зменшення глибини з 25-27 до 14-16 см та заміна оранки плоскорізним розпушуванням на ту ж глибину не супроводжується істотним зменшенням урожайності соняшнику і створює можливості для економії витрат пального та енергії. Таким чином, за наявності великої кількості наукових рекомендацій різного спрямування щодо застосування основного обробітку грунту [2-8, 10-13] вважаємо за доцільне продовжити дослідження ефективності застосування різних способів основного обробітку в технології вирощування соняшнику в конкретних грунтовокліматичних умовах Північного Степу України. Науково обгрунтований вибір системи основного обробітку грунту дасть можливість найкраще реалізувати потенціал продуктивності сучасних сортів і гібридів інтенсивного типу, які характеризуються більшою здатністю засвоювати ФАР, створювати оптимальну листкову поверхню та $\epsilon$ більш вибагливими до агрофізичних властивостей грунту.

Метою дослідження $є$ обгрунтування шляхів підвищення врожайності та рентабельності виробництва насіння соняшнику в Північному Степу України на основі вибору найбільш ефективних способів основного обробітку грунту.

Завдання - провести економічну оцінку багаторічних експериментальних даних та визначити найбільш ефективні способи основного обробітку грунту в технології вирощування соняшнику в грунтово-кліматичних умовах Північного Степу України.

Матеріали і методи досліджень. Інформаційною базою комплексного аналізу були результати експериментальних досліджень за 2012-2014 pp., що проводилися на базі ДП ДГ «Дніпро» ДУ Інституту зернових культур НАAН.

На вивчення були поставлені наступні способи основного обробітку грунту:

- оранка ПН-3-35 на 25-27 см (контроль);

- плоскорізний обробіток КПЕ-3,8 на 16-18 см;

- мілкий обробіток БДТ-7 на 8-10 см;

- нульовий обробіток грунту.

Економічна оцінка проводилася на основі застосування загальноприйнятої методики, яка дає змогу оцінити варіант технології за рівнем урожайності, собівартості виробництва одиниці продукції, прибутковості гектара посівної площі та рівнем рентабельності. Виробничі витрати розраховувалися на основі технологічних карт вирощування та діючих методичних рекомендацій $[9,14,16]$. Для розрахунку вартісних показників були прийняті ціни на виробничі ресурси та продукцію, що діяли в першому кварталі 2016 року.

Результати досліджень. Актуальною проблемою під час вирощування соняшнику в Степу України залишається забезпечення максимального рівня вологонакопичення за рахунок створення оптимальних параметрів фізичних властивостей грунту під дією його основного обробітку.

Проведені нами дослідження (2012-2014рр.) показали, що найкращі показники структурноагрегатного складу орного шару та щільності грунту забезпечувало проведення оранки. 


\section{ЕКОНОМІКА}

Економічна ефективність вирощування соняшнику залежно від застосування систем основного обробітку грунту (2012-2014 рр.)

\begin{tabular}{|c|c|c|c|c|}
\hline \multirow[b]{2}{*}{ Показник } & \multicolumn{4}{|c|}{ Системи основного обробітку грунту } \\
\hline & 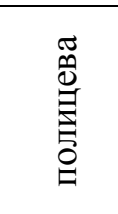 & 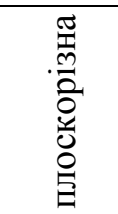 & 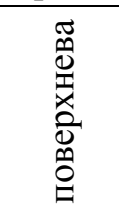 & 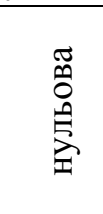 \\
\hline Урожайність, т/га & 2,67 & 2,41 & 2,22 & 1,97 \\
\hline $\begin{array}{c}\text { Виробничі витрати на } \\
1 \text { га, грн } \\
\end{array}$ & 7009 & 6756 & 6433 & 6994 \\
\hline Собівартість 1 т, грн & 2625 & 2803 & 2898 & 3550 \\
\hline Чистий дохід на 1 га, грн & 17021 & 14934 & 13547 & 10736 \\
\hline Рівень рентабельності, \% & 242,8 & 221,0 & 210,6 & 153,5 \\
\hline
\end{tabular}

Таким чином, саме у даному варіанті сформувались найкращі умови для отримання високої віддачі гектару землі.

Як свідчать дані таблиці, зменшення врожайності у варіантах з плоскорізною, поверхневою та нульовою системами основного обробітку грунту, в порівнянні з полицевою, становило відповідно 0,26, 0,45 і 0,70 т/га (або 9,7, 16,9, i $26,2 \%)$.

Економія матеріально-грошових, трудових та енергетичних витрат у розрахунку на гектар посіву в сучасних умовах $\epsilon$ визначальним фактором, який спонукає виробників віддавати перевагу безполицевим способам основного обробітку грунту під час вирощування соняшнику.

Дійсно під час застосування плоскорізної системи обробітку грунту сума економії виробничих витрат становить 253 грн/га, а поверхневої до 576 грн/га.

Застосування нульової системи основного обробітку грунту потребує додаткового застосування хімічних засобів захисту рослин, а тому економія витрат у даному варіанті в порівнянні 3 оранкою $є$ незначною і становить усього 15 грн/га.

Результати досліджень показали, що, на жаль, темпи зниження врожайності в решті варіантів в порівнянні з контрольним були досить високими, що не лише нівелювало ефект від економії виробничих витрат, але й призводило до суттєвого погіршення економічних показників.

Так, собівартість виробництва 1 т насіння соняшнику зростала у варіанті з плоскорізним способом обробітку грунту на $6,8 \%$, поверхневим способом - на 10,4\%.

Найдорожчим виявилося виробництво 1 тонни насіння у варіанті, де застосовували нульову систему обробітку грунту - 3550 грн/т, що на 35,2 \% вище, ніж на оранці.

Витратні показники відповідним чином впливали на формування показників дохідності гектару посіву та окупності витрат.

Так, на площах, де застосовували безполицеві та нульовий способи обробітку грунту, сума недоотриманого чистого доходу в розрахунку на 1 га становила від 2087 до 6285 грн/га (12,3-36,9 \%).

Виробництво насіння соняшнику під час застосування полицевої системи основного обробітку грунту забезпечувало отримання 2,43 грн чистого доходу в розрахунку на 1 грн витрачених ресурсів, тоді як рівень рентабельності в разі проведення плоскорізного обробітку грунту знижувався на 21,8 п. п., поверхневого обробітку - на 32,2, нульового - на 89,3 п. п.

Висновок. Результати проведених досліджень показали, що вирощування соняшнику $є$ високорентабельним під час застосування всіх досліджуваних систем обробітку грунту.

Водночас найкращі показники врожайності, дохідності та окупності витрат забезпечує полицева система обробітку грунту.

В умовах економічної кризи можна розглядати можливість застосування плоскорізної та поверхневих систем обробітку грунту, з яких плоскорізний спосіб є більш доцільним як 3 точки зору продуктивності культури, так і за показниками дохідності та рентабельності виробництва.

За результатами досліджень нульову систему обробітку грунту, яка потребує більш високого хімічного навантаження, у випадку вирощування соняшнику визнано недоцільною. 


\section{БІБЛІОГРАФІЯ}

1. Постанова КМУ від 11 лютого 2010 р. №164 «Про затвердження нормативів оптимального співвідношення культур у сівозмінах в різних природно-сільськогосподарських регіонах» [Електронний ресурс]. - Режим доступу : http://zakon4.rada.gov.ua/laws/show/164-2010-\%D $0 \% \mathrm{BF}$.

2. Ресурсосбережение при основной обработке почвы / [Андреев В. Л., Демшин С. Л., Нуризянов Р. Р., Козлова Л. М., Мальцев Б. П.] // Земледелие. - 2008. - №1. - С. 22-23.

3. Безуглов В. Г. Минимальная обработка почвы / В. Г. Безуглов // Земледелие. - 2002. - №4. - С. 2122.

4. Бей А. А. Плоскорезная обработка с щелеванием в почвозащитном севообороте / А. А. Бей, В. С. Сердюк // Земледелие. - 1984. - №11. - С. 20 31.

5. Белевцев Д. Н. Эффективность различных способов основной обработки почвы под подсолнечник / Д. Н. Белевцев, В. И. Медведев, Н. А. Зорин // Бюллетень научно-технической информации по масличным культурам. - Краснодар : ВНИИМК, 1977. - Вып. 2. - С. 23-26.

6. Борин А. А. Какая обработка почвы лучше? / А. А. Борин, И. Г. Меугаев // Земледелие. - 1995. №4. - C. 32-33.

7. Глухих М. А. Оптимальное сочетание способов основной обработки почвы / М. А. Глухих, Г. А. Калетин, А. А. Попов // Земледелие. - 1981. №2. - C. 36-37.

8. Гордієнко В. П. Гумусний стан грунту за різних систем удобрення й обробітку в сівозміні / В. П. Гордієнко, А. М. Крохмаль // Вісник аграрної науки. - 2006. - №11. - С. 11-14.

9. Економічний довідник аграрника / [Дробот В. І., Зуб Г. І., Кононенко М. П. та ін.] ; за ред. Ю. Я. Лу- зана, П. Т. Саблука. - К. : Преса України, 2003. C. 294-309.

10. Иванов Н. И. Обработка почвы и применение удобрений / Н. И. Иванов, В. П. Бойко, А. Ф. Витер. - М. : Россельхозиздат, 1971. - 125 с.

11. Киреев А. К. Обработка и свойства богарных черноземов / А. К. Киреев // Земледелие. 1995. - №2. - C. 15-17.

12. Медведєв B. В. Наукові передумови мінімілізації основного обробітку грунту і перспективи його впровадження в Україні / В. В. Медведєв, Т. Є. Линдіна // Вісник аграрної науки. 2001. - №7. - C. 5-8.

13. Моргун Ф. T. Обработка почвы и урожай / Ф. Т. Моргун. - М. : Колос, 1977. - С. 127-156.

14. Науково-практичний довідник по обгрунтуванню поелементних нормативів трудових, грошово-матеріальних та енергетичних витрат на виробництво зернових культур / [Черенков А. В., Рибка В. С., Кулик А. О. та ін.] ; за ред. А. В. Черенкова і В. С. Рибки. - Дніпропетровськ : Нова ідеологія, 2014. - 180 с.

15. Наумов С. Н. Возможности сокращения интенсивности обработки / С. Н. Наумов, Е. И. Иваницкая // Земледелие. - 1984. - №6. - С. 15-17.

16. Нормативна собівартість та ціни на сільськогосподарську продукцію / Ціноутворення та нормативні витрати в сільському господарстві (теорія, методологія, практика) ; за ред. П. Т. Саблука, Ю. Ф. Мельника, М. В. Зубця, В. Я. МесельВеселяка. - К. : ННЦ IAE, 2008. - Т. 2. - С. 838.

17. Тарарико А. Г. Теоретические основы почвоводоохранных систем земледелия / А. Г. Тарарико // Вісник аграрної науки. - 1991. - №9. C. 11-14. 